\title{
Some Aspects of the New Microfinance Law in Zimbabwe
}

Tsanangurai Makuyana

National University of Science \& Technology

Department of Insurance and Actuarial Science

Doi:10.5901/mjss.2017.v8n3p209

\begin{abstract}
This paper analyses the new Microfinance Act [Chapter 24: 29] in order to reveal the shortcomings in the law and to suggest areas of possible improvement. The study was carried out using a purely desktop legal research method wherein a critical review of the piece of legislation was done against the theory surrounding microfinance business principles. The study concluded that the new Microfinance Act in Zimbabwe has a considerable number of shortcomings born out of both drafting loopholes and outright lack of thrust of principles promotive of the growth of the microfinance sector in the country.
\end{abstract}

Keywords: Microfinance Act; Law; Interpretation; Consumer protection.

\section{Introduction}

Microfinance plays a critical role in the process of building inclusive financial systems for inclusive growth and development (The Reserve Bank of Zimbabwe Quarterly Microfinance Industry Report). In the period before August 2013, microfinance institutions in Zimbabwe were registered and supervised in terms of the Moneylending and Rates of Interest Act [Chapter 14:14] and the Banking Act [Chapter 24:20]. These acts provided piecemeal provisions geared towards microfinance business. In order to rectify that, in August 2013, the new Microfinance Act [Chapter 24:29] ("the Act") was gazetted. Zimbabwe is one of the few countries in Southern Africa to pass a specialised microfinance law besides Malawi. The new microfinance law in Zimbabwe was passed in 2013 and holistically regulates both credit-only and deposit taking microfinance institutions. The new Act provides for the regulation and supervision of credit-only and deposit-taking microfinance institutions as well as the amendment of the previous Acts which were used in the regulation of microfinance business (The Reserve Bank of Zimbabwe Quarterly Microfinance Industry Report). The new Act is a welcome development in the microfinance sector in that it brings about a piece of legislation specifically devoted to microfinance business which is a significant economic sector for the majority of countries in Africa. This paper therefore seeks to give a critical analysis of this new microfinance law in order to point out certain weaknesses and gaps in the law which can be improved.

\section{Rationale for Promulgating the New Law}

During the second reading of the Microfinance Bill H.B.2012 which led to the gazetting of the new microfinance law, the Minister of Finance spelt the reasons for the new law. Among other reasons, the law was expected to provide a framework that promotes fairness and equity in the provision of microfinance service. Since the legislation applicable in governing the activities of microfinance institutions was hitherto fragmented and therefore not in the interest of developing the microfinance sector, the new law is seen as a one stop legislative instrument specifically designed for the microfinance sector (See, Second Reading of the Microfinance Bill (H.B.2.2012). However, a closer look at the Act would reveal certain shortcomings which might need revision.

\section{Definition and Interpretation Problems: The Need for Clarity}

According to Madhuku (2010), the objective of interpretation is to arrive at the legal meaning of a statutory provision, which is the meaning intended by the legislature. However, sometimes the interpretation of legislative provisions is complicated by the nature of language used and the fact that some statutes would have been incompetently drafted (Madhuku,2010). Generally, statutory interpretation issues are complex and beyond the ambit of this work. Pitfalls abound in the reading of statutory provisions such that one cannot always be certain of what meaning to ascribe to a 
statute until they fully apply all the relevant tools of interpretation. Caution in that respect can be borrowed from the English case of Attorney General v Prince Ernest Augustus of Hanover 1957 AC 436 at 461, where Viscount Simonds emphasized that: "Words, and particularly general words, cannot be read in isolation; their colour and content are derived from their context. [ In that regard]no one should prefer to understand any part of a statute or of any other document before he has read the whole of it."

The new piece of legislation regulating the microfinance sector in Zimbabwe has drafting challenges likely to impact on interpretational issues. Before one gets into the detailed reading of the Act it is pertinent to note that the Act itself is fraught with some serious definitional issues. The following are some of the definitions used in the Act to provide a clearer understanding of the new law but in the process ended up confusing and compounding issues.

\section{1 "Money lending business" and "microfinance business"}

The initial definitional challenges under the Act are born out of the terms "money lending business" and "microfinance business". Although it is clear that, the new Microfinance Act in Zimbabwe was introduced partly to amend the Moneylending and Rates of Interest Act, it is difficult to understand the rationale behind the incorporation of moneylending business within the microfinance law. An examination of the two terms would reveal some reconciliation challenges regarding the understanding of both moneylending and microfinance business. Under the Microfinance Act, moneylending business is defined as "the business of providing loans or other credit facilities to persons, otherwise than as part of a credit-only microfinance business or deposit-taking microfinance business" (Section 2 of the Microfinance Act (Chapter 24:29). On the other hand, microfinance business means any person who carries on, or who advertises or announces himself or herself or holds himself out in any way as carrying on, either or both of the following:

a. moneylending business; or

b. credit-only microfinance business or deposit-taking microfinance business that is not conducted for the sole or exclusive benefit of the members of that business (Section 2 of the Microfinance Act (Chapter 24:29).

The difficulty in the foregoing definitions emanates from the inclusion of moneylending business under the microfinance business. This is so because moneylending has been defined as excluding either credit-only or deposittaking microfinance business. It therefore becomes complicated to understand how moneylending can be understood as microfinance business yet it is a business which excludes that kind of business. It is submitted that although moneylending and microfinance business may be almost similar, the two need to be clearly separated from each other. The need for clarity and certainty in law cannot be over-emphasised. The current definitions of the two terms create ambiguity. The legislature unnecessarily over-stretched the ambit of the new microfinance law to cover even moneylending business which business has hitherto been properly regulated under the Moneylending and Rates of Interest Act. It is submitted that; the law be amended to incorporate those moneylending issues it seeks to cover specifically rather than employ a blanket definitional approach which can mystify rather than simplify issues.

\section{2 "Corporate Microfinancier"}

The other definitional problem is born out of the term "corporate microfinancier". This term is defined under section 2 of the Act as a "microfinancier that is "a partnership or company referred to in section 7(1)(b)(ii) or (iii)." On the other hand, microfinancier is understood under the Act as a "moneylender, corporate microfinancier or microfinance institution" (Section 2 of the Microfinance Act (Chapter 24:29).

Two aspects of the definition seem to be problematic in a fundamental way which creates an obvious ambiguity. Firstly, the inclusion of "partnership" in the definition of an entity which is identified as "corporate" seems to be out of order. Under Zimbabwean corporate law, a partnership is not generally understood as a corporate entity because it does not have separate legal personality as is the case with a company (See Salmon v Salmon [1897]). See also the definition of Company under section 2 of the Companies Act (Chapter 23:04). It is therefore difficult to understand how a partnership is bunched together with a company as a "corporate microfinancier" when these two forms of businesses can be distinguished clearly at law without this created confusion. A redrafting of the definition possibly by substituting both "partnership" and "company" by the word "entity" would bring some semblance of clarity to the term "microfinancier."

Secondly, the term "corporate microfinancier" can undoubtedly be understood easily by looking for the meaning of "microfinancier" which is a component of the term. In recognition of that fact, the legislature defined microfinancier in the same Act (See section 2 of the Microfinance Act (Chapter 24:29)). However, instead of one getting a better understanding of the term "corporate microfinancier" through a reading of "microfinancier" alone, one gets even more entangled into a maze of terminology which is confusingly repeated. For instance, microfinancier is defined as meaning 
among other things, "corporate microfinancier". Surely this is a movement in circles which does not add any value to the interpretation of the law. The inclusion of corporate microfinancier in the definition of microfinancier seems to be a reversal of the incremental element of meanings to the understanding of both "corporate microfinancier" and "microfinancier." Poor drafting ended up ruining what could have been well-thought out explanations of words meant to aid in the understanding of the provisions of the new Act.

\section{Some Critical Content Issues}

\subsection{Application of the Act}

The Microfinance Act is applicable to a number of areas such as credit only and deposit-taking microfinance business conducted not for the benefit of members of that microfinance institution (Section 3(1)(a) of the Microfinance Act (Chapter 24:29). The Act also applies to any subsidiary or division of a registered bank in Zimbabwe engaging predominantly in the microfinance business (Section 3(1)(b) of the Microfinance Act (Chapter 24:29). However, the Act does not apply to microfinance business carried out by a body corporate established directly by any enactment to the extent that the body corporate carries out functions conferred upon it by the enactment (Section 3(2) of the Microfinance Act (Chapter 24:29). Makuyana (2016) argues that the exact import of this provision and the ambit of its application are not clear. This is so if one tries to reconcile this particular provision and section 6 which deals with the registration and prohibition in relation to conduct of microfinance business. Section 6(1)(a) of the Act provides that no person shall conduct any microfinance business unless the person is registered in terms of the Microfinance Act. It is apparent under section 6 that microfinance business is exclusively regulated under the Microfinance Act and that any purported operation of such business outside the purview of the Act will not be countenanced. It is difficult to delineate the province of non-application of the Act to microfinance business envisaged under section 3(2) of the Act. There seems to be a contradiction between section 3(2) and section 6 in that section 6 makes it clear that any microfinance business is carried out under the Act yet at the same time the Act under section 3(2) is said not to be applicable to certain microfinance business under some unnamed enactments. If, by enacting a piece of law specifically targeted at microfinance business, the legislature intended to have a focused law (See Second Reading of the Microfinance Bill (H.B.2.2012), it is submitted that this should not be taken away by some unclear provisions such as section 3(2) whose import and ambit of application are not easily fathomable.

\subsection{Renewal of registration}

Once a microfinance institution is registered the registration certificate remains valid for a period of a year "ending on $31^{\text {st }}$ December" of the year in which the microfinancier received the certificate (Section 10(1) of the Microfinance Act (Chapter 24:29). The Act defines a "financial year" in relation to a microfinancier as meaning the period of twelve months ending on the $31^{\text {st }}$ of December in any year (Section 2 of the Microfinance Act (Chapter 24:29). It is difficult to establish the reason for which the legislature decided to arbitrarily delineate a financial year as ending only on the $31^{\text {st }}$ of December. This is so because microfinance institutions can have varying financial year endings depending on the date from which an institution started operating. It could have been prudent for the legislature not to have specifically mentioned 31 December in the Act itself. This could have been achieved through stipulating that a registration certificate shall expire after one year from the date of registration of the microfinance institution concerned.

Furthermore, the expiry and renewal of a licence on an annual basis is likely to be a costly and cumbersome process for the microfinance institutions. The renewal process is likely to impact negatively on the prospect of funding from possible financiers due to perceived or real fears that a particular microfinance institution may not be able to renew its operating licence. It is submitted that a longer operating licence period of up to five years per term would have been ideal and promotive of the spirit of operating without the attendant fear of non-renewal of a licence yearly.

\subsection{Information to be displayed by microfinanciers}

The Microfinance Act requires every microfinancier to clearly display an authenticated copy of its registration in the English language (Section 15(1) of the Microfinance Act (Chapter 24:29). It is also mandatory for every microfinancier to display at its premises information regarding services it offers and information relating to the rights and responsibilities of borrowers as prescribed (Section 15(2) of the Microfinance Act (Chapter 24:29). Of significance to the foregoing requirements is that the information must be displayed in "the English language and in every other language that is spoken by a substantial number of borrowers or potential borrowers" (Section 15(3) of the Microfinance Act (Chapter 


\section{4:29.)}

The specific requirement that the information must be displayed in the English language seems to be a negation of the fact that most microfinance services' consumers in Africa are not sophisticated individuals to warrant the need for communication in the English language. It could have been better and more inclusive to simply require that information about a microfinance institution be displayed in a language(s) generally understood by the locals where the institution is located. Furthermore, it is difficult to determine the "substantial number of potential borrowers" who speaks "every other language" in order to comply with section 15(3) of the Act. This is made more complicated by the fact that the Zimbabwean Constitution recognises sixteen (16) official languages as of March 2013, after the passing of a new Constitution (See section 6 of the Constitution of Zimbabwe). The obligations imposed by the Constitution are binding on every person, natural or juristic (Section 2(2) of the Constitution of Zimbabwe). It is therefore submitted that; the new Microfinance Act should generally leave it to microfinance institutions to communicate in a language understood by their consumers without arbitrarily providing for specific languages in the Act itself.

\subsection{Requirements for lending by microfinance institutions}

In order to advance consumer rights and ensure fair play in the microfinance business sector, the Act imposes certain obligations on microfinance institutions. One of such obligations is that a microfinance institution must allow a borrower an opportunity to read the loan agreement or to have it read to him or her before he or she signs it and must provide the borrower with a copy of the agreement after the signing process (Section 26 of the Microfinance Act (Chapter 24:29).

The intended import of this requirement could have been the need to fully inform customers of the terms and conditions of the loan agreement before they get committed to a transaction whose financial repercussions could be unbearable for them. However, the way section 26(2) is worded seems to be far from serving the intended purpose. This is because all a microfinance institution is obliged to do is "allow an opportunity to read" or "to have it read to him or her" without regard to whether an explanation to ensure understanding of the meaning of the document is given or not. Given the sophistication of loan agreements and some such other financial products, it will not be enough to give a customer an opportunity to read a loan agreement and neither will it be sufficient to read out to the customer as well without meaningful explanations being offered. The legislature left it to mere conjecture that, in the process of reading out the terms and conditions of a loan agreement, its meaning will also be "explained" to the customer. Surely this assumption could prove unfavourable to consumers in that it leaves out a gap at law which could be exploited by microfinanciers to the detriment of consumers' right to transparency in dealings with service providers. It is submitted that, the legislature should have made it clear that microfinance institutions' officials are obliged not only to read out, but to explain fully the meaning of the terms and conditions of any loan agreement crafted by them.

If a microfinance institution advances credit without affording the borrower an opportunity to read the credit agreement or without first reading it out to him as required by section 26(2) of the Act, no interest shall be payable on the advance and the capital sum of the advance shall not be recoverable from the borrower (Section 26(3)(a)(b) of the Microfinance Act (Chapter 24:29). It seems that failure by a microfinance institution to give out a copy of the loan agreement even after having read out the agreement to the borrower would still render it non-compliant with the requirements of the Act. It is also unclear why the legislature intended a harsh penalty such as non-payment of interest on the advance or non-recovery of the principal sum to be meted out when other non-business discouraging remedies such as re-directing the institution to comply with the provision could have sufficed. An approach which would promote the growth of the microfinance sector at the same time affording consumers some form of protection would be more desirable than a command-control approach. In the second reading of the Microfinance Bill, which led to the promulgation of the current Act, the Minister of Finance made it clear that, there was need to put in place a legal framework promotive of growth of the microfinance sector (See Second Reading of the Microfinance Bill (H.B.2.2012).

\subsection{Alteration of memorandum or articles of association by microfinance institution}

A microfinance institution is prohibited from altering its memorandum or articles of association or other rules for the conduct of its business unless the Registrar has given his consent to the alteration (Section 32 of the Microfinance Act (Chapter 24:29). The Registrar is given further powers to refuse to consent to an alteration if in his or her opinion the alteration conflicts with any provision of the Microfinance Act (Section 32(2) of the Microfinance Act (Chapter 24:29)

It is submitted that regarding the alteration of the memorandum or articles of association the Registrar seems to command far and wide powers. The powers of the Registrar in this regard are tantamount to interference with the internal processes of microfinance institutions, which, for all intents and purposes, are companies. Section $6(1)(b)$ of the 
Microfinance Act clearly spells it out that no person shall be registered as a microfinance institution unless that person is a company. This therefore means that, a microfinance institution is a company first before it is legally a microfinance institution in terms of the Microfinance Act. The implication of this reading of the law is that, a microfinance institution is a company to which the provisions of the Companies Act (Chapter 24:03) regarding the alteration of the memorandum or articles of association can mutatis mutandis apply.

Section 16(1)(a) of the Companies Act (Chapter 24:03) provides that a company may, by special resolution, alter any condition contained in its memorandum which could lawfully have been contained in the articles of association, unless the memorandum itself prohibits the alteration. Regarding the articles of association, section 20 of the Companies Act (Chapter 24:03) provides that, a company may by special resolution alter or add to its articles and any alteration or addition so made in the articles shall be as valid as if originally contained therein.

It is clear that, the alteration of the memorandum or articles of association under the Companies Act is done by the company itself through a special resolution. It is difficult to establish how the Registrar of microfinance institutions should give his consent for an institution to alter its memorandum or articles of association which are purely company documents to which the regulator should have access through returns filed with him. It is submitted that there is nothing wrong with the Registrar exercising his discretion to refuse to recognise an alteration which, in his opinion, contravenes the Microfinance Act and which contravention can at the end be reversed by him. However, for the Registrar to have default powers to decide the correctness or otherwise of an alteration before it is even carried out seems to be stretching his powers a bit far. This anomaly can be dealt with through an amendment of the Microfinance Act to simply permit microfinance institutions to be able to alter their memorandum or articles of association but coupled with the safeguard that the Registrar can reverse such alteration if it is found to be in breach of the Act.

\subsection{Restriction on other business that may be carried out by microfinance institutions}

The new law restricts microfinance institutions to carry out certain business ventures. However, it is unclear as to what type of microfinance institution the restriction on the carrying on of business applies. A reading of section 29 of the Act bears a contradictory interpretation as to which microfinance institution, deposit-taking only or credit only institution, is being envisaged under the provision. According to the provision, unless approved by the Registrar "no microfinance institution shall" carry out any other business other than approved microfinance business (Section 29(1) of the Microfinance Act. (Chapter 24:29). Clearly, the wording suggests an all-encompassing restriction to both credit only and deposit taking microfinance institutions by its being non-specific. However, section 29(2) which is a proviso to the section, seems to bring in a different interpretation altogether by specifically mentioning "deposit-taking" microfinance institutions. The confusion created by the proviso to the section makes it difficult to establish with certainty, the intention of the legislature on the type of microfinance institution restricted. There is a maxim of statutory interpretation which states that, the express mention of one or more things is meant to exclude the others of the same class that are not mentioned (Maduku,2010). In that regard, one might argue that the specific mentioning of deposit-taking institution under section 29(2) was clear indication that, those were the type of microfinance institutions the entire provision intended to restrict (See also, Lead Smelting Co v Richardson1762 (3) Burr 1341; Intro Properties (UK) Ltd v Sauvel 1984 (2) All ER 495). It is submitted that for the avoidance of doubt the provision needs to be revisited for a possible amendment to clear the obvious ambiguities currently present.

\subsection{Insider loan regulation}

Microfinance institutions are prohibited under the Act from knowingly extend credit to any of its officers or directors; or any relative of the officers of the institution on terms and conditions that are more favourable than those on which the institution, applying criteria normally applied in the microfinance industry, would extend credit to other persons of the same financial standing (Section 30(2) of the Microfinance Act (Chapter 24:29). However, the prohibition shall not be construed to prevent a microfinance institution from extending credit to one of its employees, where the credit is extended as part of the employee's conditions of service and is available to other employees (Proviso to section 30(2) of the Microfinance Act (Chapter 24:29).

Although it is clear that the foregoing provisions of the Act relate to the regulation of insider loans and the granting of loans to counterparties related to those employed by the microfinance institution, the extent of the prohibition is not that clear. For instance, it is not easily fathomable whether what is being prohibited are loans to relatives only or loans to relatives on favourable terms than those to other persons of the same financial standing or both. Such ambiguity can be cured by simplifying the structuring of the provision and clearly stating the mischief against which the law is aimed at 
preventing.

\subsection{The contributory aspect of microfinance institutions}

The Microfinance Act requires every microfinance institution in Zimbabwe to be a contributor for the purpose of the Deposit Protection Act [Chapter 24:29] (Section 35 of the Microfinance Act (Chapter 24:29). One of the major objectives of the Deposit Protection Act is to establish a Deposit Protection Fund for the compensation of depositors in the event of financial institutions becoming insolvent (See preamble to the Deposit Protection Act. See also section 5 of the Deposit Protection Act (Chapter 24:29). What is clear from the Deposit Protection Corporation's function is that, it is there to protect small depositors through the establishment of a deposit insurance scheme to which institutions such as banks which take deposits from members of the public, should contribute. Microfinance institutions can either be credit only or deposit-taking microfinance institutions (See section 2 of the Microfinance Act (Chapter 24:29). It is therefore a ridiculous requirement under section 35 of the Microfinance Act to require every microfinance institution to be a contributor for the purpose of the Deposit Protection Act even if such a microfinance institution does not take any deposits from members of the public for which protection is needed through the Deposit Protection Corporation [see (Makuyana,2016) for a detailed critique]. It is submitted that deposit-taking microfinance institutions only should be required by the Act to be contributors for the purpose of the Deposit Protection Act since they take deposits from customers just like banks.

\subsection{Consumer protection under the Microfinance Act}

A legal framework for recognizing and enforcing consumer protection is a major requirement for financial consumer rights to be fully realised in the microfinance sector (World Bank, 2012). It is to be understood that one of the numerous aims of regulating the microfinance sector is the need to safeguard the interests of the vulnerable and uneducated consumers (Arun and Murinde, 2005). Furthermore, vulnerable and/or illiterate consumers should not only be protected, but also empowered (Du Preez,2009). Informed and empowered consumers are a powerful social and economic force in society (Mupangavanhu,2012).

Due to competition in the microfinance sector, providers of microfinance services sometimes resort to inappropriate marketing strategies and predatory methods of promoting their products. Currently there is no specialised law in Zimbabwe devoted to consumer protection. However, the legislature recently gazetted the Consumer Protection Bill of 2014 which is hoped to be of broader application and protection to consumers including consumers of financial services. The Bill's main purpose, inter alia, is to promote a fair, efficient and transparent marketplace for consumers and business. The Bill also proposes the promotion of consumer rights and the provision for improved standards of consumer information and the prohibition of unfair competition, marketing and business practices. It also provides for a fundamental bill of consumer rights (See Preamble to the Consumer Protection Bill 2014.) However, it is the consummation of these rights in practice or their protection by the courts which will go a long way to prove if indeed the rights of consumers are going to be realised.

According to Beltran (2007), "Consumer protection pertains to measures that promote the rights of clients, enable them to make informed choices and protect them from unscrupulous acts that deny them the true value and optimum benefits of microfinance services..."

It is in light of the foregoing definition that the new microfinance law in Zimbabwe has to be assessed against its letter and spirit in the securing of financial consumer needs (Makuyana, 2016). The law provides for various consumer protection safeguards in their dealings with providers of microfinance services. The provisions are analysed under the following sub-headings for clarity purposes.

\subsubsection{Requirements for loan agreements}

The Microfinance Act makes it mandatory for every loan agreement to which a microfinancier is party, to be in writing, setting clearly all its material terms and conditions. The law also requires the loan agreement to permit the borrower to make a partial or total pre-payment of any amounts owed by the borrower under the contract. The agreement should also specify any penalties for payments of amounts owed by the borrower under the contract. Although the requirements for loan agreements are clearly meant to safeguard the interests of consumers, the final consummation of the mischief intended to be prevented rests with the implementation of such provisions. For instance, the Reserve Bank of Zimbabwe as the regulator of microfinance institutions has recently raised concerns about institutions which inadequately disclose terms and conditions of loans including interest rates, and failure to provide borrowers with loan agreements (Reserve 
Bank of Zimbabwe Quarterly Microfinance Industry Report). Such reportage is clear evidence of implementation challenges of laws faced by financial regulatory authorities.

The Act also provides for a pro-consumer protection microfinance code of conduct which when fully implemented can result into the realisation of value for consumers. Microfinanciers are obliged to desist from adopting undesirable methods of conducting business particularly by failing to comply with the Code of conduct. The Code of conduct provides for transparency, client education and financial literacy among other progressive elements under the Act. Microfinanciers under the Code are obliged to follow practices built on respect, fair treatment, persuasion and courtesy towards clients. Under the transparency principle the Act provides for full disclosure to clients and potential clients of all terms and conditions pertaining to any of the financial services offered by the microfinancier. The disclosure must be made in plain and simple language understood by the client. This disclosure in simple and plain language is a fundamental right under section 14 of the Consumer Protection Bill recently gazetted but not yet in force in Zimbabwe. The Reserve Bank of Zimbabwe as the regulator of microfinance institutions in the country has recently reported an upsurge in complaints regarding issues to do with exorbitant charges and interests rates being levied by some errand microfinanciers (Reserve Bank of Zimbabwe Quarterly Microfinance Industry Report). This is despite the fact that, the Microfinance Act obliges every microfinancier to provide clients with documents clearly indicating the rate of interest, terms of repayment, collateral required from the client and details of all charges other than interest (if any).

It is evident that the rationale behind the disclosure requirements under the Code is to avail relevant information to customers so that they can be capacitated to make informed decisions about their preferences when dealing with microfinanciers. The Microfinance Code of Conduct is a commendable input in the Act. Makuyana (2016), points out that responsible microfinancing is one of the driving spirits behind the Microfinanciers' Code of Conduct under the Microfinance Act.

\section{Dispute Resolution under the Microfinance Act}

An efficient dispute resolution mechanism is central to the growth of any sector, the microfinance sector included. The alternative dispute resolution mechanism benefits both the consumer and the supplier by bridging the gap between an unresolved matter and litigation (Law Reform Commission 2008). The process is relatively affordable and empowering to the consumer, and is not time consuming (Paleker ,2003). The procedure consequently increases access to justice (Mupanangavanhu,2012).

The new Microfinance Act in Zimbabwe provides for a grievance mechanism to settle disputes which may arise in the microfinance sector. Under section 9(1) of the incorporated Microfinance Code of conduct, every microfinancier is obliged to institute a procedure for dealing with complaints from clients and ensure that every complaint is attended to and remedied within reasonable time. The Microfinancier is also required by law to make the complainant aware of their right to complain to the Registrar of microfinance institutions if their complaint is not remedied to their satisfaction. Although the provision regarding the grievance procedure is a well-intended one, it is the enforcement or the commitment to enforcement which makes any difference for the complainants. There is also need to oversee the activities of microfinanciers to establish the levels of compliance of such dispute resolution mechanism. It is submitted that the biggest shortcoming of the grievance procedure lies in the rationale of leaving it to microfinanciers to deal with complaints which they may have caused in the first place. It is rather absurd that institutions, for which laws are meant to regulate, are authorised to be adjudicators in their own cases which may raise suspicion of bias on the part of complainants.

The right to complain to the Registrar for which consumers must be alerted by microfinanciers is provided for under PartVIII of the Microfinance Act which is devoted to the enforcement of microfinanciers' Code of conduct. The enforcement mechanism provided for under this part is long, complicated and likely to be of less use by average consumers of microfinance services. Generally, consumers are interested in receiving a quick solution to their problems through direct negotiation rather than in asserting their rights through a long, winding tedious process (Law Reform Commission,2008). The complaints procedure commences by the lodging of a complaint with the Registrar who will then inform the Secretary and the secretary will then instruct a disciplinary committee to meet and investigate the complaint. Makuyana (2016) argues that, the outcome of the investigation and hearing under section 48 of the Act is a victory to the regulator rather than the complainant because any microfinancier found guilty of undesirable methods of conducting business will be made, among other things, to pay a fine to the central bank. It is submitted that consumers of microfinance services are likely to benefit more from employing the dispute resolution mechanism under the Consumer Protection Bill when it is passed into law because it is arguably more progressive than what currently obtains under the Microfinance Act. The Consumer Protection Bill provides for a robust dispute resolution mechanism for consumers. Some of the major highlights of the Bill in this regard, are the establishment under section 5 , of the Consumer Protection 
Commission and the Consumer Court under section 43. The Bill also provides for the realisation of consumer rights and it gives a broad locus standi in judicio to various institutions and individuals to enforce rights in any of the given judicial fora. The broad-based approach to consumer protection enshrined in the Bill is likely to be of positive impact to microfinance consumers when the Bill is passed into law anytime soon.

\section{Evaluation and Analysis}

Except for a few highlighted definitional and interpretational issues, the new Microfinance Act in Zimbabwe is, in the main, a progressive piece of legislation. The Act's philosophical grounding is the need to protect consumers of microfinance services. A significant highlight of the progressive nature of the legislation is the provision for the Microfinanciers' Code of Conduct ("the Code") in the First Schedule of the Act. Central to the operational basis of the Code is the need to treat clients fairly and with courtesy (See section 1 of the Microfinanciers Code of Conduct). The Code, among other things, advocates for transparency by requiring microfinanciers to fully disclose to their clients and potential clients all terms and conditions attaching to any of the financial services offered, in plain and simple language understood by the clients (See section 4 of the Microfinanciers Code of Conduct). Emphasizing the need for maximum consumer protection, the Act imposes on all microfinanciers an obligation to avoid over-indebtedness of their clients and by prohibiting microfinanciers from using stressful debt recovery methods such as the detaining of ATM cards as a security for any loan facility (See sections 5 and 6 of the Microfinanciers Code of Conduct).

However, there is need to relook at the Act to address certain issues already highlighted in the foregoing paragraphs such as poor drafting, powers of the Registrar and scope of application of the Act among other things. The Act's dispute resolution mechanism leaves a lot to be desired and will less likely be of any meaningful use to average consumers of microfinance services(Makuyana,2016). One of the biggest shortcomings of the Act is the non-provision for the establishment of an independent agency specifically devoted to the overseeing and enforcing of consumer rights and other related issues. To leave it to the Reserve Bank of Zimbabwe to supervise microfinance institutions will be of less meaningful gain to consumers of microfinance products and even to the microfinance institutions themselves considering that, the central bank is also the regulator of other numerous financial institutions such as banks. In the main it is submitted that the Microfinance Act be amended to suit the needs of institutions which it intends to regulate. For instance, provision should be made for the establishment of an independent supervisory agency specifically for the microfinance sector and for the formation of stakeholder organisations interested in the microfinance sector. Such organisations when recognised under the law will gain legitimacy and visibility in the sector, thereby promoting the sector's growth in the long term.

\section{Conclusion}

The Zimbabwean new Microfinance Act is a step in the right direction in the promotion of financial inclusivity through regulation. The progressive stance of the Act is more apparent in consumer protection through a code of conduct of microfinanciers. However, it being a pioneering piece of legislation regulating a specialised field of microfinance the Act is fraught with some irregularities which if removed or rectified, the law will become more certain and clear of any ambiguities.

\section{References}

\section{Books}

Arun T. and Murinde V., (2005). Microfinance regulation and Social Protection

Beltran G. S., (2007) Microfinance Consumer Protection Guidebook. National Credit Council, Manilla Philippines

Madhuku L., (2010) Introduction to Zimbabwean law, Weaver Press, Harare, Zimbabwe

\section{Journal Articles}

Du Preez M.L. (2009) "The Consumer Protection Bill: A few preliminary comments" TSAR p.58

Makuyana, T., (2016) "Microfinance Regulation and Supervision in Zimbabwe: A Critical Overview" Mediterranean Journal of Social Sciences, 7(1), p.376.

Mupangavanhu Y., (2012) "An analysis of the dispute settlement mechanism under the consumer protection act 68 of 2008 " Potchefstroom Electronic Law Journal 5(15), p.320 
Paleker M., (2003) "Court connected ADR in civil litigation: the key to access to justice in South Africa" ADR Bulletin p. 48.

\section{Working papers and Reports}

Reserve Bank of Zimbabwe, (2014) Quarterly Microfinance Industry Report.

World Bank, (2012) Good Practices for Financial Consumer Protection. Washington D.C USA

\section{Internet Sources}

Law Reform Commission, (2008) Consultation Paper: "Alternative Dispute Resolution" www.lawreform.ie/_fileupload /consultation\%20papers/cpADR.pdf [Date of use 2 Dec 2016]

\section{Register of Cases}

Attorney General v Prince Ernest Augustus of Hanover 1957 AC 436

Intro Properties (UK) Ltd v Sauvel 1984 (2) All ER 495

Lead Smelting Co v Richardson1762 (3) Burr 1341;

Salmon v Salmon [1897].

Register of Statutes

Companies Act (Chapter 23:04)

Consumer Protection Bill, 2014.

Deposit Protection Act (Chapter 24:29)

Microfinance Act, (Chapter 24:29)

Microfinance Bill, 2012. 
ISSN 2039-2117 (online)

ISSN 2039-9340 (print)
Mediterranean Journal of Social Sciences MCSER Publishing, Rome-Italy
Vol 8 No 3

May 2017 